Investigating teachers' perception on the importance of teachers' certification and of professional development program in Indonesia: An empirical study from Bali

Agung, Anak Agung Gede

Universitas Pendidikan Ganesha - Singaraja - Bali, Indonesia (agung2056@yahoo.co.id)

Gading, I Ketut

Universitas Pendidikan Ganesha - Singaraja - Bali, Indonesia (Ketutgading35@gmail.com)

Werang, Basilius Redan $\bowtie$

Universitas Musamus - Merauke - Papua, Indonesia (lirang267@yahoo.co.id)

Sudiarta, I Gusti Putu

Universitas Pendidikan Ganesha - Singaraja - Bali, Indonesia (gussudiarta@yahoo.de)

Marti, Ni Wayan

Universitas Pendidikan Ganesha - Singaraja-Bali, Indonesia (wayanmarti@yahoo.com)

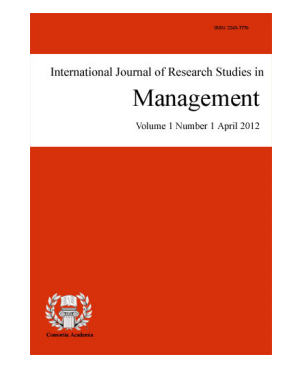

ISSN: $2243-7770$ Online ISSN: 2243-7789

OPEN ACCESS

\title{
Abstract
}

This study aimed at describing: (a) the perceptions held by a group of teachers in Bali Province on the importance of teachers' certification program; and (b) the perceptions held by a group of teachers in Bali Province on the importance of their professional development program. Two research statements guided this study are: (a) what are teachers' perception of the importance of teachers' certification program? and (b) what are teachers' perception of the importance of their professional development program? This study employed a quantitative approach using survey research design. A purposive sampling was used to obtain 26 respondents drawn from amongst teachers in three selected districts of Bali Province, namely Buleleng District ( 8 teachers), Jembrana District ( 9 teachers) and Denpasar City ( 9 teachers). Quantitative data were analyzed descriptively. This study finds that: (a) $77.78 \%$ of teachers percept negatively on the importance of teachers' certification program; and (b) $81.81 \%$ of teachers percept negatively on the importance of their professional development program. These findings might be worthwhile for the Indonesian government to evaluate to what extent the teachers' certification program had a positive impact on teachers' professionalism in teaching practices. These findings might be also worthwhile for the Education Office at Bali Province to creating some innovative program of enhancing teachers' participation in professional development program in order that students' right to be taught by professional teachers are met adequately.

Keywords: teachers; perception; certification; professional development; program; Bali 


\section{Investigating teachers' perception on the importance of teachers' certification and of professional development program in Indonesia: An empirical study from Bali}

\section{Introduction}

Teachers around the world enter the profession for different reasons (e.g. enjoy teaching, working with children, and to give children the best possible start in life), but all of them share the need for appreciation, autonomy, and affiliation during their professional career (Hargreages et al., 2006; Symeonidis, 2015). In order to appreciate the role of teachers in building up the future life of the young, Indonesian government has provided a legal foundation, recognized as Indonesian Law No. 14/2005 on Teacher and Lecturer, for improving the quality, competency and welfare of teachers. Amongst many others component, this law aknowledges the crucial role of teachers in ensuring the success of the reform of the education system and, in turn, change educational policies and strategies, particularly regarding the areas of teacher management and development (Jalal, Samani, Chang et al., 2009).

The number of studies have been in different countries to explore the nature of certification and the need for teachers' professional development (Guskey, 1995; Hassel, 1999; Guskey, 2000; Bolam, 2002; Boyle, While, \& \& Boyle, 2004; Hargreaves, Cunningham, Everton et al., 2006; Gabriel, Day, \& Allington, 2011; Aminudin, 2012, MacBeath, 2012; Symeonidis, 2015; Winarti, 2016), but the absence of studies on this topic in Bali, Indonesia, makes this study robbust. Given an urgent need of improving the quality of teachers and, in turn, the quality of education, this study focuses on the effort of describing teachers' perception on the importance of teachers' certification and of professional development program in Bali, Indonesia.

We do believe, understanding teachers' perceptions of their certification might be worthwhile for the government and the certification program's provider to evaluate the implemented program in order that the right of approacing retirement teachers to be recognized and certified in advance is adequately met. Besides, understanding teachers' perception on the importance of their professional development program might be imperative for the Office of Education of Bali Province to create the way of boosting teachers' motivation to actively participate in the professional development programs offered in order that students' rights of having professional teachers are also met adequately. To investigate the perceptions, we employ quantitative approach using survey design which we explain briefly below.

\section{Related Literature}

\subsection{A Brief Look on Teacher's Status}

Teachers around the world enter the profession for different reasons (e.g. enjoy teaching, working with children, and to give children the best possible start in life), but all of them share the need for appreciation, autonomy, and affiliation during their professional career (Hargreaves et al., 2006; Symeonidis, 2015). MacBeath (2012) argued that wherever teachers have been asked about their priorites and satisfiers, In South Africa, Sub-Saharan Africa, Europe, or North America, they refer to the importance of recognition and respect for their daily challenges. To the MacBeath's (2012) argument, Symeonidis (2015) wrote as follows:

Teachers' positive sense of their status is closely linked to other aspects of quality education, including continuous professional development, engagement in research, collaboration and exchange with other teachers, and involvement in decision making. In this respect, education unions are the most appropriate agents to help teachers improve their status by influencing educational policies (p. 14). 
General perception of teacher' status as seen as 'average' in all education sectors. A study conducted by Symeonidis (2015) reported that over half of the respondents showed a decline in teacher status over the last 10 years. To argue the findings, Symeonidis (2015) wrote as follows:

Different in status between teaching and other occupations, as well as changes in status over time were mainly attributed to salaries and working conditions, the quality of teacher education programmes, standards for entering the profession, media image, government consultation with unions and teachers, truts in teachers' professional judgement, and the extent to which market-based policies are introduced in certain coutries ( $\mathrm{p} 10)$.

In order to improve teachers' status and teaching profession, the following policy should be prioritized by all education stakehoders (Symeonidis, 2015, p. 13):

> Provide high quality teacher education, professional development opportunities, and attractive career prospects;

$>\quad$ Improve salaries and working conditions;

$>$ Ensure academic freedom, autonomy and involvement in decision-making;

$>$ Advocate for strong public education system placed at the centre of local communities and a positive representation of teachers in society;

$>$ Regular dialogue between eduacation unions and government. A more active role for unions in education policy formulation and implementation can ensure that professional issues and the welfare conditions of teachers will be effectively addressed. Teachers' involvement in policy development can ensure that the needs of students are also effectively addressed as teachers are best placed to understand what these needs are.

A concern to improve teacher's status and the teaching profession has been globally inherent in government policy. In international level, Unesco's Special Intergovernmental Conference on the Status of Teachers held in 1966 produced an extensive list of recommendations to improve the status of teachers. Thirty years later, the International Commission on Education for the Twenty First Century return to the issue (Delors, 1996). As a follow up of these two great efforts, Education International, in 1998, held a Congress in Washington DC which passed a resolution on teachers' status. Since then, the status, not only of teachers, has been a topical research area (Hargreaves et al., 2007). In Indonesia, a concern of improving teachers' status and the teaching profession has been inherent in the Law No. 14/2005 on Teacher and Lecturer. Amongst many other components of the educational system, this law focuses on the national education reform that requires change to education policies and strategies, particularly regarding the areas of teacher management and development.

\subsection{Teachers' Professional Development}

So far there is no universal agreement yet on what professional development is. The Glosary of Education Reform, for example, defined professional development as variety of specialized training, formal education, or advanced professional learning intended to help administrators, teachers, and other educators improve their professional knowledge, competence, skill, and effectiveness. Meanwhile, Cambridge Business English Dictionary defined professional development as the training that is given to managers and people working in professions to increase their knowledge and skills.

Boyle et al. (2004) asserted that "the continual deepening of knowledge and skills is an integral part of the professional development of any professional working in any profession" (p. 46). The term 'professional development' here refers directly to 'teacher professional development'. Bredeson (2002) highlighted a plethora of terms that are used interchangeably with the term 'teachers' professional development' such as teachers' in 
service training, teachers' continuing education, teachers' development, and teachers' self-improvement. Guskey (1995) asserted that this may happen as the concept of teachers' professional development could be viewed from several different perspective. Hassel (1999) defined teachers' professional development as the process of improving teachers' skills dan competences needed to produce outstanding educational results for students. Despite the lack of concensus among scholars about definition of the term, most of the literature defined teachers' professional development as an intentional, on going and systematic process (Guskey, 2000; Bolam, 2002; Gabriel et al., 2011) of both formal and informal education, training, learning and support activities holding in either outside or inside of worked-based setting (Hawley \& Valli, 1999; Bolam, 2002).

Variety of studies have showed us of how important the teachers' professional development program is (e.g. Craig, 1998; Hasell, 1999; Guskey, 2000; Sparks, 2002; Mizell, 2010; Caena, 2011; Aminudin, 2012). Guskey (2000), for example, stated, "One constant finding in the research literature is that notable improvement in education almost never take place in the absence of professional development" (p. 4). Cardno (2005) stated that teachers' professional development is important to ensure the sustainability and growth of teaching profession.

\subsection{Analytical Framework}

Based on related literature investigating teachers' perception on the importance of teachers' certification and of professional development program, the analytical framework of this present study is as presented in Figure 1 below.

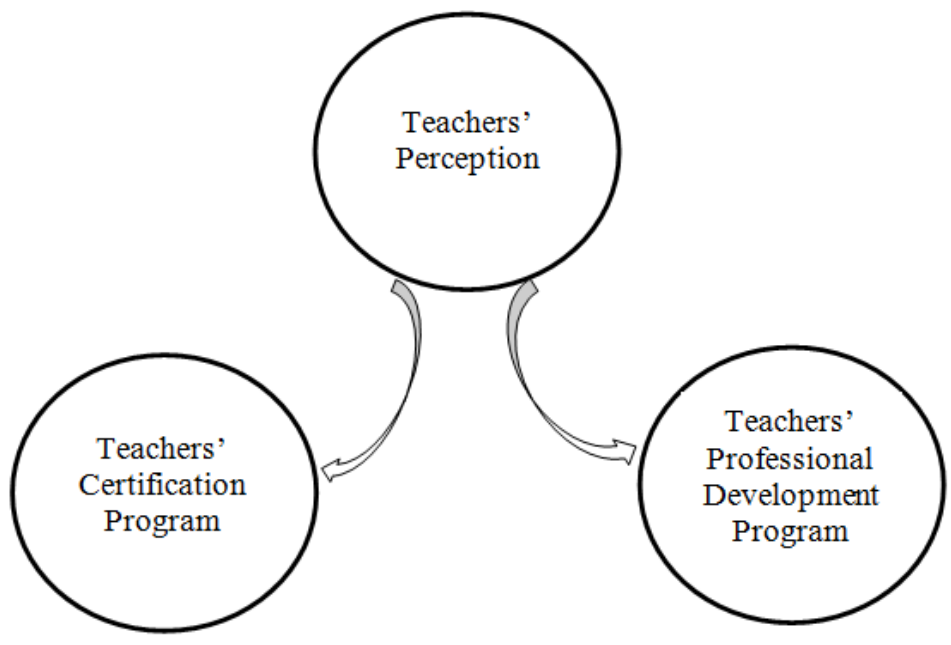

Figure 1. Analytical of the Study

\section{Method of the Study}

\subsection{Design and Participation}

In this study we employed a quantitative approach using a survey design due to the following considerations: (a) high representativeness; (b) low cost; (c) convenient data gathering; (d) good statistical significance; (e) little researchers subjectivity; and (f) precise results. Using a quantitative approach, teachers' perceptions on the importance of teachers' certification program and of teachers' professional development program were explored based on questionairres. Two questionairres administered to 26 teachers of three selected district of Bali Province, namely Buleleng district (8 teachers), Jembrana district (9 teachers), and Denpasar city (9 teachers). Samples were drawn purposively due to the limited personnel and the time limit established by the sponsor. Quantitative data were analyzed descriptively to describe teachers' perception on the importance of teachers' certification and of teachers' professional development program. 


\subsection{Measures}

Teachers' perception on the importance of teachers' certification program was measured by developing nine positive statements. The inventory used a two point scale (aggree $=1$ and disaggree $=0$ ). Respondents are requested to respond each statement on a scale of two alternatives, that are agree (A) and disagree (D). Sample of items include "quality of education is really improved through teachers' certification", 'teachers' certification is the government way of rewarding teachers who have good performance in teaching", "government prioritize teachers who have long taught to be in advance certified", "teachers' certification is a very attractive program as it is able to increase teachers' welfare", "certified teachers are attractive to develop their professional in teaching".

Teachers' perception on the importance of teachers' professional development program was measured by developing eleven negative statements. The inventory used a two point scale (aggree $=1$ and disaggree $=0$ ). Respondents are requested to respond each statement on a scale of two alternatives, that are agree (A) and disagree (D). Sample of items include: "teachers have already been professional when graduated from colleges/universities", "teachers' professional development program is aimed at boosting teachers' prestige only", "actually, teachers' professional development program is no longer needed after certification", "teachers' professionalism in teaching is mainly indicated by teachers' welfare".

\section{Findings of the Study}

This study aimed at describing teachers' perception on the importance of teachers' certification program and of teachers' professional development program. As stated above, quantitative data was analyzed descriptively. The results od data analysis on teachers' perception on the importance of teachers' certification are reflected in Table 1 below.

\section{Table 1}

Teachers' Perception on the Importance of Teachers' Certification Program

\begin{tabular}{ccc|cc}
\hline \multirow{2}{*}{ Items } & \multicolumn{2}{c}{ Positive (YES) } & \multicolumn{2}{c}{ Response } \\
\cline { 2 - 5 } & Number & $\%$ & Number & $\% 4.61$ \\
\hline 1. & 4 & 15.39 & 22 & 84.61 \\
2. & 4 & 15.39 & 22 & 33.77 \\
3. & 18 & 66.23 & 8 & 65.38 \\
4. & 9 & 34.62 & 17 & 92.31 \\
5. & 2 & 7.69 & 24 & 57.69 \\
6. & 11 & 42.31 & 15 & 34.62 \\
7. & 17 & 65.38 & 9 & 69.23 \\
8. & 8 & 30.77 & 18 & 65.38 \\
9. & 9 & 34.62 & 17 & \\
\hline
\end{tabular}

Data in Table 1 showed that 7 items of questionnaires (77.78\%), out of 9 , were responded negatively (NO) by the majority of respondents. Only 2 items of questionnaires, out of 9 , were responded positively (YES) by the majority of respondents. It means that the majority of respondents in three selected districts of Bali Province percept negatively to teachers' certification program.

Meanwhile the results of data analysis on teachers' perception on the importance of teachers' professional development program are reflected in Table 2. Data in Table 2 showed that 9 items of questionnaires $(81.81 \%)$, out of 11, were responded positively (YES) by the majority of respondents. Only 2 items of questionnaires $(18.19 \%)$ were responded negatively (NO) by the majority of respondents. Since all the items of questionnaires are negatively formulated, then all the YES answers should be interpreted as NO answers and, in reverse, all the NO answers should be intrepreted as YES answers. In this context of view, the majority of respondents in three selected districts of Bali Province percept negatively to teachers' professional development. 
Agung, A. A. G., Gading, I. K., Werang, B. R., Sudiarta, I. G. P., \& Marti, N. W.

Table 2

Teachers's Perception on the Importance of Teachers' Professional Development Program

\begin{tabular}{ccc|cc}
\hline \multirow{2}{*}{ Items } & \multicolumn{2}{c}{ Positive } & \multicolumn{2}{c}{ Negative } \\
\cline { 2 - 5 } & Number & $\%$ & Number & 57.69 \\
1. & 11 & 42.31 & 15 & 53.85 \\
2. & 12 & 46.15 & 14 & 3.85 \\
3. & 25 & 96.15 & 1 & 15.39 \\
4. & 22 & 84.61 & 4 & 7.69 \\
5. & 24 & 92.31 & 2 & 7.69 \\
6. & 24 & 92.31 & 2 & 34.61 \\
7. & 17 & 65.39 & 9 & 26.92 \\
8. & 19 & 73.08 & 7 & 23.08 \\
9. & 20 & 76.92 & 6 & 19.23 \\
10. & 21 & 80.77 & 5 & 26.92 \\
11. & 19 & 73.08 & 7 & \\
\hline
\end{tabular}

\section{Discussion}

Indonesian Government, in December 2005, passed the Teacher and Lecturer Law in order to provide teacher with more opportunities for knowledge and skills training through a certification process, as well as mandating them to improving the quality of education. This present study was conducted to investigate of how certified teachers percepting and valueing the great effort of implementing the teacher quality management reform. Surprisingly, out of 9 items questionnaires distributed to the respondents, 7 items were responded negatively by the majority of respondents. This finding demonstrates that the majority of respondents valued less advantages on the certification program held in Bali Province. For teachers, the main indicator of the quality of education was the welfare of teachers. Based on the result of the study, the majority of respondents were attracted to teachers' certification program due to their belief that the welfare of teachers $(66.23 \%$, see item 3$)$ and the quality of education $(65.38 \%)$ were brought along with. The rest items were responded negatively by the majority of respondents mainly due to the following: (a) government and certification program provider as well were not fair since they failed to prioritized teachers who are approaching retirement; (b) government and certification program provider were not fair when newly appointed as civil service has already certified than those teachers who have long been appointed as civil service; and (c) portfolio was not an appropriate way of certifying and measuring teachers as professional.

Since teachers do not finish learning with graduation, this present study was also conducted to investigate teachers' perceptions on the importance of teacher' professional development program held in Bali Province. More surprisingly, out of 11 items questionnaires distibuted to the respondents, 9 items $(81.81 \%)$ were positively responded by the majority of respondents. As it was stated in the 'results' section, since all the items of quastionnaires were negatively formulated, then all the 'YES' answers should be considered as 'NO' answers. In this context of view, the majority of respondents viewed less advantages on the teachers' professional development program held in Bali Province. For teachers, since teachers were not paid fairly and teachers' welfare was still low. Based on the result of this present study, the majority of respondents percepted negatively to the professional development program mainly to the following: (a) the belief that teachers have been professional when graduated from the university; (b) teachers' professional development program aimed at boosting teachers' prestige only; and (c) teachers' professional development program was no longer needed after certification.

Independent of how teachers percepting their certification and professional development program, teachers are no doubt playing a pivotal role of educating the future productive citizens of tomorrow to contribute to the broader well-being of both a society and a nation. In this context of view, teachers should focus on enabling students to learn more than they would on their owncand to improve the possibilities that each student can 
Teachers' perception on teachers' certification and professional development program in Indonesia

realize their potential, regardless of their situation in life (Corrigan, 2016). In order that teachers are able to handle all the tasks and responsibilities given to them and are able to "embrace uncertain, complex and challenging context and work with other to seek creative and innovative solutions that support quality outcomes for all" (Australian Institute for Teaching and School Leadership, 2015, p. 6), teachers should be well trained, educated, and equipped with all the competences needed (Werang et al., 2016).

\section{Conclussion, Implications, and Recommendation}

This research was conducted with the aim to describe teachers' perception on the importance of teachers' certification and of professional development held in their respective districs of Bali Province, Indonesia. The conclussions depicted from the results of the study are follows:

The majority of sampled teachers (77.78 \%) in three selected districts of Bali Province, in fact, percept negatively to the practive of teachers' certification program held in Bali, mainly due to the following reasons: (1) portfolio is not the right way for teachers' certification; (2) not fair if newly appointed civil servants have already got a teaching certificate then those who have long been civil servants; and (3) teachers who are approaching retirement should be prioritized but the fact is not.

$>$ The majority of sampled teachers (81.81\%) in three selected districts of Bali Province, in fact, percept negatively to the concept and practice of teachers' professional development programs held in Bali Province, mainly due to the following reasons: (1) the main indicator for teachers' professionalism is the improvement of teachers' welfare; (2) there must be no charge to attend professional development for certified teachers; (3) in-service professional development did little change to teachers' teaching practice; and (d) teachers have already been professional after graduate.

Practical and theoretical implications of our findings are follows:

Practical Implications - Teachers' perception on the importance of teachers' certification program held in Bali only be improved if the following matters should be seriously considered by both government and teachers' certification provider: (1) teachers who have long been taught should be certified in advance than those newly appointed as civil servants; (2) designing a new appropriate way for teachers' certification; and (3) teachers who are approaching retirement should be prioritized in certification program.

Teachers' perception on the importance of teachers' professional development held in Bali only be improved if the following matters should be seriously considered by both governemnt and teachers' professional development program providers: (1) teachers' welfare; (2) teachers' must be continually assured of the need for professional development to facing the new challenges of teaching profession; and (3) professional development should be well designed in order to give more advantages for teachers' practice of teaching.

Theoretical Implication - Since the topic of this study is still lack in Indonesia context and has never been conducted in Bali, findings of our present study may theoretically add the existing literature on the importance of certification and of professional development program in helping teachers to meet today's challenges.

Since our present study is limitted on the effort of investigating teachers' perception on the importance of teachers' certification and of professional development program held in Bali. Therefore, a more study on the impact of teachers' professional development on both teachers' professionalism and teachers' teaching practice are fully recommended.

Acknowledgement - We are really grateful for the support of Director of Research and Community Services of Higher Education in Jakarta who has funded all the process of this study. We would like to thank all the teachers who have actively participated and contributed in a special way to the study. 


\section{References}

Aminudin, N. A. (2012). Teachers'perception on the impact of professional development on teaching practice: The case of one primary school (Masteral thesis). Unitec Institute of Technology.

Australian Institute for Teaching and School Leadership. (2015). Australian professional standard for principals and the leadership profile. Retrieved from https://www.google.com/\#q=Australian+Institute+for+Teaching+and+School+Leadership.+Australian+P rofessional+Standard+for+Principals+and+the+Leadership+Profile, $+2015 \& * \& b \operatorname{tnK}$

Bolam, R. (2002). Professional development and professionalism. In T. Bush \& R. Bell (Eds.). The principles and practice of educational management (pp. 113-118). London: Paul Chapman.

Boyle, B., While, D., \& Boyle, T. (2004). A longitudinal study of teacher change: What makes professional development effective? Curriculum Journal, 15(1), 45-68. https://doi.org/10.1080/1026716032000189471

Bredeson, P. V. (2002). The architecture of professional management: Materials, messages and meaning. International Journal of Educational Research, 37(8), 661-675. https://doi.org/10.1016/S0883-0355(03)00064-8

Caena, F. (2011). Quality in teachers' continuing professional development. European Commission. Directorate-General for Education and Culture.

Cambridge Business English Dictionary. (n/d.). Professional development. Retrieved from http://dictionary.cambridge.org/dictionary/english/professional-development

Cardno, C. (2005). Leadership and professional development: The quiet revolution. International Journal of Educational Management, 19(4), 292-306. https://doi.org/10.1108/09513540510599626

Corrigan, D. (2016). What is the role of a teacher. Retrieved from http://theconversation.com/what-is-the-role-of-a-teacher-64977

Craig, H. J.; Kraft, R. J., \& Plessis, J. D. (1998). Teacher development. Making an impact. Washington DC: World Bank.

Dellors, J. (1996). Learning: The treasure within. Report to Unesco of the international commission on education for twenty-first century. Paris: Unesco.

Gabriel, R., Day, J. P., \& Allington, R. (2011). Exemplary teacher voices on their own development. Phi Delta Kappan, 92(8), 37-41. https://doi.org/10.1177/003172171109200808

Guskey, T. R. (1995). Professional development in education: In search of the optimal mix. In T. R. Guskey \& M. Huberman (Eds.), Professional development in education: New paradigms and practices (pp. 114-131). New York: Teachers College Press.

Guskey, T. R. (2000). Evaluating professional development. Thousand Oaks: Corwin Press.

Hargreaves, L., Cunningham, M., Everton, T., Hansen, A., Hopper, B., McIntyre, D., Maddock, M., Mukherjee, J., Pell, T., Rouse, M., Turner, P., \& Wilson, L. (2006). The status of teachers and the teaching profession. Interim Findings from the Teacher Status Project.

Hargreaves, L., Cunningham, M., Hansen, A., McIntyre, D., \& Oliver, C. (2007). The status of teachers and the teaching profession in England: Views from inside and outside of the profession. Retrieved from https://www.education.gov.uk/publications/eOrderingDownload/RR831B.pdf

Hassel, E. (1999). Professional development: Learning from the best. A toolkit for schools and districts based on the national awards program for model professional development. Oak Brook, Illinois: North Central Regional Educational Laboratory.

Hawley,W. D., \& Valli, L. (1999). The essential of effective professional development. In L. Darling-Hammond \& G. Sykes (Eds.), Teaching as the learning profession: Handbook of policy \& practice (pp. 127-150). San Francisco: Jossey-Bass Publishers.

Jalal, F., Samani, M., Chang, M. C., Stevenson, R., Ragatz, A. B., \& Negara, S. D. (2009). Teacher certification in Indonesia: A strategy for teacher quality improvement. Jakarta: Departemen Pendidikan Nasional Republik Indonesia.

McBeath, J. (2012). The future of the teaching profession. Brusells: Education International. 
Teachers' perception on teachers' certification and professional development program in Indonesia

Mizell, H. (2010). Why professional development matters. USA: Learning Forward.

Organization for Economic Cooperation and Development. (1998). Education at glance. Retrieved from https://www.oecd.org/berlin/43541636.pdf

Reading First Notebook. (2005). Why is professional development so important? Retrieved from https://www.google.co.id/?gws_rd=cr,ssl\&ei=CouyWN2bN8XM0gSn4JmgAw\#q=studies+on+the+imp ortance+of+teachers+professional+development.pdf

Sparks, D. (2002). Designing powerful professional development for teachers and principals. Oxford: National Staff Development Council.

Symeonidis, V. (2015). The status of teacher and the teaching profession. A study of education union's perspective. Belgium: Education International Research Institute.

The Glosary of Education Reform. (2013). Professional development. Retrieved from http://edglossary.org/professional-development/

Werang, B. R., Lopatty, M., \& Tambajong, H. (2016). The effect of principals' transformational leadership on schools' life in Indonesia: An empirical study in elementary schools of Merauke district. International Journal of Research in Social Sciences, 6(10), 256-273. 
Agung, A. A. G., Gading, I. K., Werang, B. R., Sudiarta, I. G. P., \& Marti, N. W. 